\title{
THE MEANING OF THE WORD ins THROUGH ANCIENT EGYPTIAN HIEROGLYPHIC TEXTS
}

\author{
Eltoukhy, M. \\ Egyptology dept., Faculty of Archaeology, South Valley Univ., Luxor branch, Luxor, Egypt \\ E-mail: mohsen.eltoukhy@arch.svu.edu.eg
}

\begin{abstract}
The word ins is related to the red color in general, ins which means the "Red Linen/Cloth" is derived from it, expressing a material/garment in the texts, it gives the meanings of red linen, red cloth, red garment/ fabric, and red bandage/mummifying bandage, also it happened that it was used in different positions related to divine names/ titles (such as: nb-ins, nbt-ins, jmj-ins. $f$, and insjij), each of them is related to a specific God (Osiris, Re, Hathor, Mut, Sekhmet, Bastet, and Sekhmet-Bastet-Rat ); also there is a feast related to ins (h3b-ins). Also the word inst which is a plant, which could be with red flower could be derived from ins. This paper is dealing with the word ins, its different writings in different positions, each gives a special meaning, and it is importance to be participated in several divine names in Ancient Egypt until the end of the late period and before the Greco-Roman period.
\end{abstract}

Keywords: ins, inst, 'Insytl 'Insj, Red linen, Nb-ins, Nbt-ins, Jmj-ins.f, 'Insjtj

\section{Introduction}

The word ins gives the meaning of Red Linen/Cloth [1] the red color is associated with the feelings of arousal, disturbance, anger, danger, and fury, and it is considered as an intense color that increases blood pressure and elevates muscle strength. It makes sense that the early Man was chiefly concerned with matters of survival, and his first foray into the world of color would be red, that it is a life-giving and protective color. So it is associated with blood, fire, and the sun to demonstrate the power that gives life or causes harm [2]. There are at least four other words related to the red color together with ins in Ancient Egypt [3]; $d \check{s} r$ [1,3], tms [1,3], $\underline{t} r$ [1,3], and jdmj or $j d m i t[1,3] ; d \check{s} r$ was used generally referring to the red color, also there are two divine names that include the word $d \check{s} r$; $N b$-dšrw [4] giving the meaning of
"Lord of blood/lord of the red"; and B3jmj-dšrw.f [4] giving the meaning of "The Ba, that is in its blood". Although, ins was only considered as the red blood color, insj is the one that appeared in divine names as: $N b$-ins [4] giving the meaning of "Lord of the red cloth", Nbt-ins [4] giving the meaning of "The Mistress / Lady of the red linen", Jmjins.fl Jmj-ins [4] giving the meaning of "The one who is in his red linen", and 'Insjtj [4] giving the meaning of "The two ladies of the red linen". However, Jéquier [5] defined it as a light red cloth, which seems to have been reserved for worship and funerary ceremonies. Thus, the word ins had not been studied separately at all only a few mentioning without clarifying the difference between the various writing or mining. 


\section{Methodology}

\subsection{Phonological point of view}

There is a possibility that ins, insj, and inst are giving the same meaning as a red garment; but inst could be referring to the red linen that normally is written as

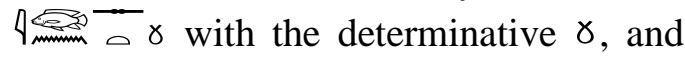
the word linen is written as

followed by the same determinative; depending on that inst could be used to determine the red linen not the red cloth, and ins/ insj could be used to determine the red cloth. The word ins [1] was written as:

\begin{tabular}{l|l|l}
\hline \multicolumn{1}{c|}{ ins } & \multicolumn{1}{|c|}{ Determinative } & \multicolumn{1}{c}{ Meaning } \\
\hline In & NON & Red (blood) \\
\hline In & "w & Red (blood) \\
\hline
\end{tabular}

The word insj [6] was written as

\begin{tabular}{|c|c|c|}
\hline insj & Determinative & Meaning \\
\hline प & 党 & Red cloth/ linen \\
\hline प & $\gamma$ & Red linen/ fabric \\
\hline $4 \sum_{\text {minn }}$ & $\gamma$ & To color something \\
\hline
\end{tabular}

The word inst [1] was written as

\begin{tabular}{c|l|l}
\hline \multicolumn{1}{c|}{ inst } & \multicolumn{1}{|c}{ Determinative } & \multicolumn{1}{c}{ Meaning } \\
\hline 4 & & (Red) plant from Wadi- \\
Natrun [7] \\
Aniseed? [8]
\end{tabular}

There is a remarkable writing that appeared in Teti PT 285d (line 242) [9] in which the determinative of the word insj was an unusual sign in in the word ins 4 m 1 速, which I couldn't find anywhere else, however, the same word appeared in the variant text of Unas PT 285d (line

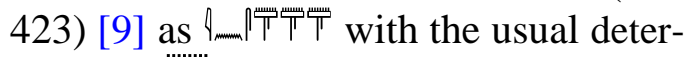
minative $\mathbb{T}$. The Ancient Egyptian word

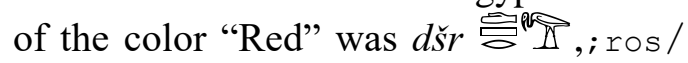
twrs in Coptic [1], this word in general was used as an adjective referring to a red material. However, all of the Coptic words I found cannot be an evolution of the word insj which gives the same meaning of red color! Which might mean that this word didn't last to Coptic although it has appeared in a Ptolemaic Hieroglyphic text, the demotic writing of insj is $Z<01 \geq \backsim$ [10], as in: Mythus Z2, 29 [11]

$3 n$ tj.k šs $n$ wit $n$ inst $n T-n t-p 3$... hnt

"Have you not taken a red bandage and green cloth for the (goddess) of ... the Mistress of Joy?"

In addition, the word ins appeared with $d \check{s} r$ in the same sentence in Pepi
[9] PT 1464a (line 781) with two other variants:

Pipi pw ins pr $m$ 3st pw dšr pr $m$ Nbt-hwt

"Pepi is the red linen / pink-color that came from Isis (and) the redness that came from Nephthys" [12,13]

It has to be noted in these variants that ins was translated as the red linen/ pink color that came from Isis, although $d \check{s} r$ was translated as redness that came 2.1.1. inst as a colored cloth

The writing inst as a red colored cloth was used in several texts with dif- from Nephthys, depending on that, ins could refer to lighter degree of red color than $d \check{s} r$.

ferent positions as could be seen in the following phrase: 
* CT II 227, S1P Spell 149 [14]

dd $s \underline{t} b \mathrm{~b}$ h $\underline{d}$ jdmj snd $m n \underline{d}$ inst

"Be shod with a pair of white Sandals <and be clad in> a kilt and sash? of red linen" [15]

The word $m n \underline{d}$ in this example is that it is not common to be as a followed by ${ }^{ \pm 灬}$ which could be considered determinative of the word $m n \underline{d}$. as a defective writing of the word inst; * pAn. III-A, 8 = pBM EA 10246/6 [16, 17, 18, 19, 20] with the determinative $\gamma$ with the three strikes of plural n3y.sn h3w.tj $m$ inst

"their beginnings / tops are made of red inst fabric"

* pAn. IV , 16.7 = pBM EA $10249[16,17,18,21]$ with the determinative $\gamma$ n3y.sn h3w.tj $m$ inst

"their tops are of red inst fabric"

* pAn. IV, $17.2=$ pBM EA $10249[16,17,18,21]$ with the determinative $\gamma$ n3y.sn krtw $m$ inst

"their straps are of red inst fabric"

* pBM EA $10085+10105$ (Miscellanies), On the Delivery of Foreign Goods (line [x $+3.10])[22]$ $j w . \underline{b} b 3 n d w$ ins $\{t\}$

"You (f.) are clothed with the red fabric (?)"[23]

\subsection{2. insw a colored cloth}

The writing insw as a red colored cloths was also used as a mummifying

bandage [24] and linen bandages, as follows:

* pRamesseum 9 = pBM EA 10762, 2,1-3,10 (line 2,2-3) [25]

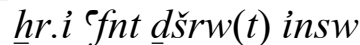

"The ones who are under their red headscarves and linen bandages!"

In addition, the word $f^{\prime} n w$ could give the meaning of blindfolded or cov-

\subsection{3. insj as a colored cloth}

The writing insj as a red colored cloth was also used in several texts with ered, also it could be give the meaning of a sandals [26]

different positions as could be seen in the following phrases:

* pKoller 3.8 = pBerlin P 3043, 3.3-5.4: Letter on Nubian Tribute [16,17,27,28,29,30] $n b w$ nfr gmw $n$ ḩst $m$ 'rf $n$ insj

"white gold, good gold, from the mountains (?) in red linen cloth bags"

* Magical Papyri New Kingdom, pLeiden I 346, Proverb III (line 3,9) [31]

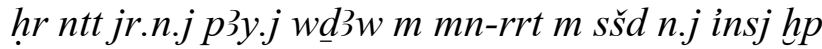

"For I have made my amulet in the form of such a piglet of red linen bandage."

* pTurin Museo Egizio 1791 Tb 114-165, Tb 164 (line 13) [32]

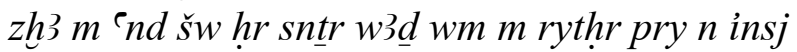

"(It is) to paint with dried myrrh resin (mixed) with ("on") fresh frankincense and to trace ("repeat") with ink on a red cloth bandage."

\subsection{Producing the insj as a garment}

There are specific verbs that appeared with insj as a red colored mate-

rial; such as psi and $n b d$ in the following example.

* Nouh, p. 146 [6] 
di.i rh.k $n 3$ wỉ wt nty imj Hwt-ntr..... nbd psi insj

"I inform you/ I cause you to know the jobs that are in the temple.... and the one who cooks/ dyes the red linen (insj)"

Berlandini-Grenier has also mentiests specially those of the Goddess oned that rk ins appeared with the priBasstet [33].

\subsubsection{Place of insj}

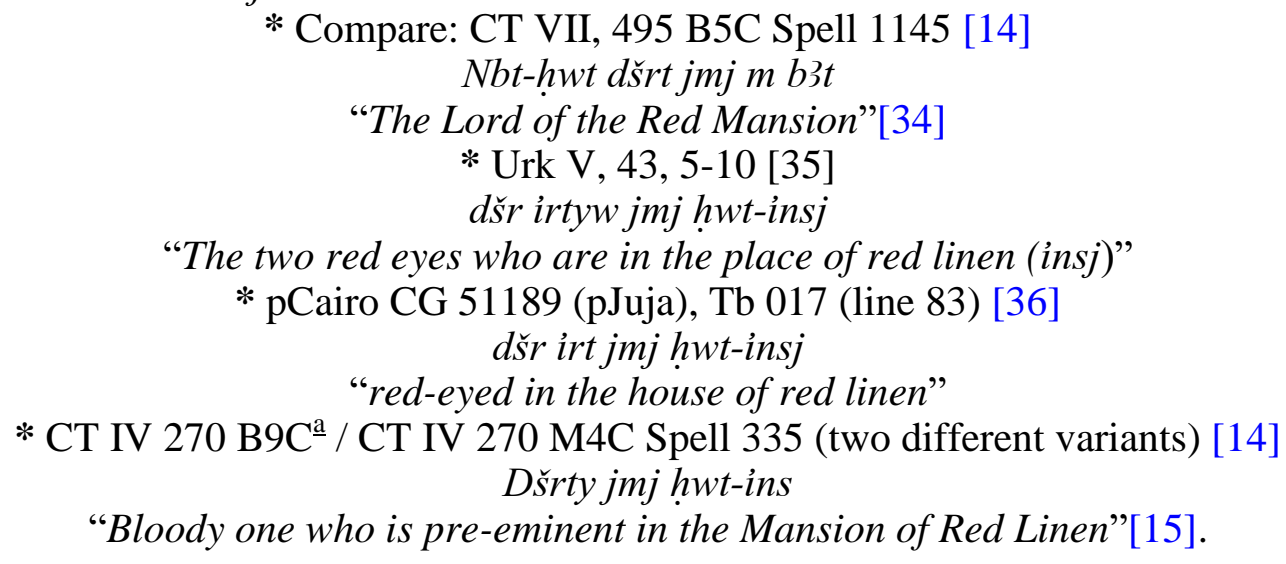

$d \grave{s} r t y$ as a Nisbe form of the noun $d \check{r} r$ is followed by jmj hwt-ins as an epithet, the whole phrase is considered as a name of one of the seven spirits that is followed by the determinative of God A40 from the sign-list of Gardiner.

\section{3. insj as a divine symbol}

Heba Nouh [6] mentioned that there a ritual with four kinds of colored linen with $h \underline{d} t$ (white), w3 $\underline{d} t$ (green), idmjt (dark red), and inst (light red), this ritual is related to Goddess Neith as a specific linen named $m n h t$; this linen was used to cover the face during the mummification by Neith or one of her
The other six spirits are: Dhdh, $3 k d k d$, "Bull who was not put to his burning", "black-faced who is in his hour", "Radiantfaced who comes out after having turned back", and "He who sees in the night what he shall bring by day" [15].

subordinates whose name was hndwt. These linen were made and prepared in two chapels named rsnt and mhnt [37, $38,39]$. Horus was wearing this cloth during his fight with Seth [40], also it was used with statues [41]. It appeared also as a Magical bandage named pry made of the ins, as:

* Totb. Leps. 164, 12 [6]

$s \check{s} m$ 'nd hr w3 $\underline{d}$ mry hr pry $m$ ins

"Spreading oil on the offspring with love on the bandage of ins (red fabric)"

\subsubsection{Feast of insj}

It is noted that there is the word ins that gives the meaning of "female priest" from the Greek era [1] but I couldn't find it with the determin-

ative B1 in Gardiner's Sign-list, which could mean that there was a Goddess named ins, who had a specific feast, as appeared in the followings:

\section{* Unas pyramid, PT 250 (line [398]) [9].}

[268b] jn Wnjs dd jm.t jb wrt $m$ h(3)b ins

"It is Unas who says what is in the heart of the great, on the feast of the red linen cloth." [12]

* CT VII 101, S10C Spell 890 [14]

jnk shn w3yt ..... n h(3)b-ins $m$ nhpw

"I am he who sought her who is far away on the day of the festival of red linen in the early morning" [34]

* pParis Louvre 3092 + Frgm. Montpellier (pNeferubenef), Tb 174 (line 515) [42] 


\section{dd jmjt jb wr $m$ ḩß̧b-insj}

"Say what is in the heart of the Great, on the feast of the red cloth!"

* pSalt 825, 2.7-9 [43]

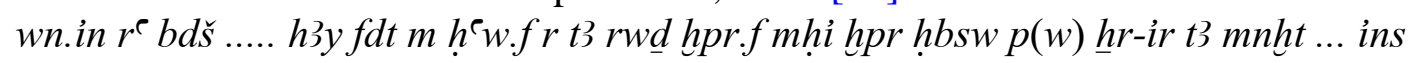
jdmyt hprw $m$....

"When Re becomes weak ... sweat came down from his body to the land IIIII/ he became.....

This example shows how insj was created on the land by God Re. All the feast of ins didn't say much about that texts that had mentioned that there is a

2.3.2. insj as an offering:

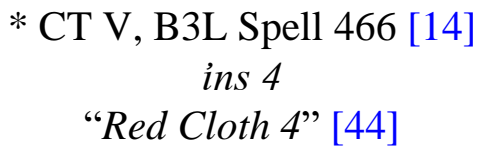

* Stela of Pu 1:2 [45] From the tomb of 'Imn-htp (middle of the XVIII Dyn. - NK) at Abydos it appeared that insj as a red linen cloth was used as an offering to be used in making the $s \check{s} d$ of the $w 3 g$ fest, which gives the deceased the right to use the holy bark of Osiris, as:

$s \check{s} p(. i) s \check{s} d m h(3) b-w 3 g \mathrm{~g} m$ w $\underline{d} \underline{d} t h r$ insj

"May I receive fillets in the feast of Uag, of green and red cloth!" [46]

The same thing appeared in Pyr. 1202 [6]

* Serabit El-Khadim, Mines, n. 53, 13-14 [47]

dd.f iw in.n.i n.s w $\underline{d}$ m msn tp $3 k t$ h $\underline{d}$ tšs ins

"He says: I brought to her an altar of faience, fine linen, white linen, various ... together with ins-cloth" [48]

\subsection{Derivatives of 'Insj}

insj is also appeared in a few epithets related to divine names such as 2.4.1. insyt

It normally appeared in the writing A in the Hieroglyphic texts [1] and it refers to "The Red Eye of Horus", there is a very rare writing 4 , dated 2.4.2. $N b$-ins

It gives the meaning of "The Lord / Master of the red linen", as an

\subsubsection{Osiris}

Most of the examples of $\mathrm{Nb}$-ins are related to Osiris in which they are

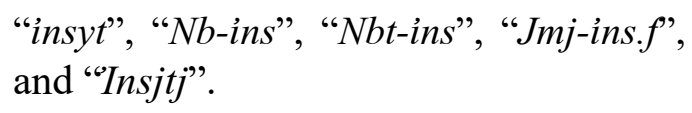
and "Insjtj".

back to the Greek and Roman periods, in which the determinative D6 of sign list of Gardiner could refer to Horus's eye.

epithet, it appeared only with god Osiris and Wnn-nfr, as follows:

mostly used as epithets for him, as follows:

* pCairo CG 25095 (pM3j-hr-prj), Tb 099 B (line [207-209]) [36]

ij.n.i m33 jt.i j Wsir j Nb-[208] insj shm $m$ 3wt-jb jnbj kp t3y [209] skd.wt

"I came to see my father Osiris. O Lord of the red cloth having joy"

There are other variants $[32,36]$ of the same formula from $\mathrm{Tb} 099 \mathrm{~B}$, most of them has the vocative prefix $j$ before the epithet $\mathrm{Nb}$-insj except pLondon BM EA 10477 (pNu), Tb 099 B (line 3) in which the vocative prefix is omitted. 
"You are trodden on and broken, from Onnophris, the lord of the red cloth"

It strictly a goddess's epithet, but here applied to Osiris, and the 0 is therefore superfluous [1]. But in the Book of the Dead, ch. 99, the skipper of a ferryboat in the netherworld is addressed as 'lord of the red cloth' [35,50,51]. Caminos [49] has a theory that $t$ in $n b t$ is a superfluous, depending on another example from pBM 10188, 17, 13 (9.22) $[52,53]$, in which wnn-nfr is followed by $n b t$; his theory could be criticized through the following: $\mathrm{Nb}$-ins appeared only in two different texts; TB 099 B in which $N b$-ins was considered as an epithet,

\subsubsection{Nbt-ins}

It gives the meaning of "Lady of the red linen" [4], as an epithet, it was written as obsil, and $\sigma$. I couldn't find any example of this epithet before New Kingdom, however, actually in pCairo CG 24095 [36]; pCairo CG 51189 [36]; pTurin Museo Egizio $1791[32,54]$ there was a vocative article separating Wsir and the so-called epithet $N b$-ins, which means that it could be a name of another god. The other example is in pBM 10288 II, 27 in which Nbt-ins was considered by Caminos as an epithet of $W n n-n f r$. OR it could be written right as Nbt-ins which appeared in many examples as a title of different goddesses, so it is normal to be used referring to one of these goddesses in a conjunctive with Wnn-nfr.

most of the examples are dated back to the Greek and Roman Periods [4]. This epithet normally refers to any of the goddesses Mut, Sekhmet, Bastet, Hathor, and Sekhmet-Bastet-Rat, as: 2.4.3.1. Mut

\subsubsection{Sekhmet [56]}

$$
\begin{gathered}
\text { * Chester Beatty IX vso, 2,5 [55] } \\
\text { Mwt nbt-inswt } \\
\text { "Mut, The lady of inst-cloths" }
\end{gathered}
$$

* Magical Papyri New Kingdom, pLeiden I 346, Proverb III (line 3,10) [31]

$$
\text { jnk shmt } n b t<r>\underline{d} \text { r jnk shmt nbt insj }
$$

"I am Sekhmet, the all-mistress, I am Sekhmet, the all-mistress"

Another example with no clue of the goddess whom this epithet refers to, which could be the goddess Sekhmet

* Fabric Strip E 997.02.11 Civic Archaeological collection, Milan [57] ...r.t $m$ t3 $m h$ h dw3t $m$ nfrw.s 'nht mr shm.ti $m$ hwt $m$ t3 imntt hmt $m \underline{d}$ w M3nw nb-ins $m r$ sthnt nb mnit hnt š̌št ir s3 $n$...

"Goddess in the land of the north and in the netherworld in her beauty that lives of loving, powerful as a lady (?) in the land of west, mistress in the hell of Manu, lady of the linen, who loves to shine, mistress of the necklace mnit, which protects ...."

\subsection{4. jmj-ins.f}

This epithet is written as $4-14$

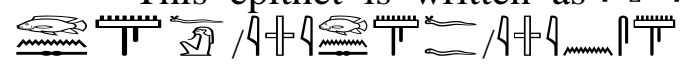

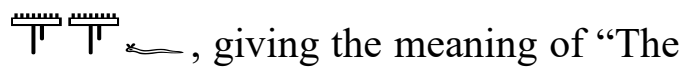
one who is in his red linen".

$$
\begin{gathered}
* \mathrm{~B} 4 \mathrm{~L}^{\mathrm{b}} \text { Spell } 154 \text { [58] } \\
R^{\complement} p w \text { hp } n \text { sw jmj-ins.f hft }{ }^{`} \text { fr.f }
\end{gathered}
$$

"It is happened that Re met Him who wears bright-red cloth [59] before he could direct his hands against him". 


$$
\begin{gathered}
\text { * B1L Spell } 619 \text { [14] } \\
\text { dw3.sn m phrt.f } m \text { s3 jmj-ins.f }
\end{gathered}
$$

"(Whom) they worship in his peregrinations in protection of him who is in his red linen"

* B3B0 Spell 622 [14]

dw3.n.k $R^{`} w$ m prw tm $s 3$ wr jmj-ins. f Nb-htpw

"You worship Re in the loosing from fetters by means of the amulet of the Great One who is in red linen, the lord of offerings" [4]

* W. 422-423/ T. 242 Pyr. 285d

[285c] $m 3 . k r^{\ulcorner} m$ jthn.t.f $d w 3 . k R^{\ulcorner} w$ m prwt.f [285d] $m s 3 w r j m j-i n s . f$

"You praise the sun at his coming out of his bonds with Great-protection, He in his red fabric" [15]

The only difference here was in the determinative of the word ins which appeared at T. 242 with the determinative , as mentioned before.

\subsubsection{Insjtj:}

This divine name is written as

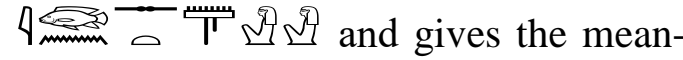

ing of "The two ladies of the red linen"

* B4C Spell 748 [14]

\section{(s3)wt $n b$ žs $d w$ insjtj Ps $\underline{d}$}

"......The two daughters of the Lord of the Thunderbolt(?), the two women belonging to the red linen, and the Sunshine-god(!)" [44]

It is not clear if 通 has to be read as $\mathrm{Jtn} / \mathrm{Hnmmt/R}$ / Hntj, but I used Psd to match the translation made by Faulkner. May be this name refers to the two Goddesses Basstet and Sachmet that both of

\section{Results}

Concerning the derivations of the word ins, there are lots of different writings that include the root ins, all of them are related to the red color; inst, insw, and insj there is a very slightly different in meaning between these three derivations, inst that is more about the fabric, insw is more about being a bandage, and insj is more about cloth. However, them held the epithet Nbt-ins and both of them are surly / ruthless and related to the blood more than the other goddesses who held the same epithet.

there are other combinations in which the root ins is the nucleus of the combined word; insyt, $\mathrm{Nb}$-ins, $\mathrm{Nbt-ins,} \mathrm{Jmj-}$ ins.f, and Insjtj all of these combinations are related to at least one of the Egyptian Gods, as a title, or an epithet. There are a few derivations with different meanings that could be shortened in table (1)

Table (1) Some derivations with diff-erent meanings

\begin{tabular}{cccc}
\hline Writing & Transliteration & Translation & Determinative \\
\hline ins & ins & Red (blood) & NON \\
\hline & insy & Red (blood) & Red cloth/ linen \\
\hline
\end{tabular}




\section{Discussion}

Through explaining the above mentioned results it has become clear from the translations, and comments of Ancient Egyptian Texts that the word ins is a very important word. Where, it appeared in many different kinds of texts, where it appeared in religion texts, such as PT, CT, and TB as a metaphor when it comes to the Royal King Pipi $[12,13]$. It seems that he was an ins himself, and there is a feast that is related to the same word as attested previously by Nouh [6], De Buck [14], Faulkner [44], Petrie [45] and Gard- iner \& Peet [47]. Also it appeared in magical texts as a bandage, or mummification bandage, and sometimes as an offering. Furthermore, in the literature texts, it appeared as normal red cloth/ garment, which needs to be produced [6] and has its own place or house $[14,15$, $34,36]$. Thus, the word ins had to be a part of the divine epithets in general, so it was found as a nucleus in a few combinations that refer to a specific God.

\section{Conclusion}

In summery; ins refers to a red linen/ cloth when the determinative $\mathrm{w}^{\mathrm{m}}$ is used, however, it refers to a red fabric when the determinative $\gamma$ is used. There are a few divine epithets that are derived from the word ins and refers to a specific God; $N b$-ins refers to Osiris and Wnn-nfr, Nbt-ins refers to Mut and Sekhmet, Jmj-ins.f refers to $R e$, although 'Insjtj is not clear to determine which goddess does it refer to.

\section{References}

[1] Erman, A. \& Grapow, H., (1982). Wörterbuch der ägyptischen sprache, $7 \mathrm{Vol}_{\mathrm{s} .}$, Akademie-Verlag, Berlin.

[2] Van Benthem, H., (2006). Coloring the ancient Egyptian world, The J. of the Egyptian Study Society, Vol. 17 (1), pp: 17-19.

[3] Schenkel, W., (1963). Die Farben in ägyptischer Kunst und Sprache, Z̈̈S, Vol. 88, pp. 131-147.

[4] Leitz, C., (2002). Lexikon der ägyptischen Götter und Götterbezeichnungen, $7 \mathrm{Vol}_{\mathrm{s}}$., Peeters Pub \& Department of Oriental Studies, Leuven.

[5] Gustave, J., (1922). Matériaux pour servir à l'établissement d'un dictionnaire d'archéologie égyptienne, BIFAO, Vol. 19, pp. 1-271.

[6] Nouh, H., (1988). Textile in ancient Egypt, MA, Egyptology dept. Faculty of Archaeology, Cairo Univ, Egypt.

[7] Germer, R., (2008). Handbuch der altägyptischen heilpflanzen, Philippika: Marburger Altertumskundliche Abhandlungen, Wiesbaden.

[8] Manniche, L., (1989). An ancient Egyptian herbal, British Museum Pub., London.
[9] Sethe, K., (1908), Die altägyptischen pyramidentexte, Vol. 1, J. C. Hinrichs'sche Buchhandlung, Leipzig.

[10] Erichsen, W., (1954). Demotisches glossar, Ejnar Munksgaard, Kopenhagen.

[11] Spiegelberg, W., (1917). Der ägyptische mythus vom sonnenauge-der papyrus der tierfabeln-"Kufi": Nach dem leidener demotischen papyrus I 384, Strassburger Druckerei and Verlagsanstalt, Strassburg.

[12] Allen, J., (2005). The ancient Egyptian pyramid texts, Writings from the Ancient World 23, Society of Biblical Literature Atlanta, USA.

[13] Shmakov, T., (2012). Critical analysis of J. P. Allen's the ancient Egyptian pyramid Texts, http://www. egy ptologyforum.org/bbs/Shmakov_Criti cal_analysis_PTs_vs1. pdf, (23/10/ 2018).

[14] De Buck, A., (1956). Coffin texts: Texts of spells 472-786, Vol. 6, University of Chicago Press, Chicago.

[15] Faulkner, R., (1973). The ancient Egyptian coffin texts, spells 1-354, Vol. 1, translations and notes, Aris \& Philips, Warminster. 
[16] Gardiner, A., (1937). Late-Egyptian miscellanies, Édition de la Fondation Égyptologique Reine Élisabeth, Bruxelles.

[17] Caminos, R., (1954). Late-Egyptian miscellanies, Oxford Univ. Press, London.

[18] Tacke, N., (2001). Verspunkte als gliederungsmittel in ramessidischen schülerhandschriften, in: SAGA 22, Heidelberger Orientverlag, Heidelberg.

[19] Erman, A., (1923). Die literatur der Aegypter, J. C. Hinrichs'sche Buchhandlung, Leipzig.

[20] Haikal, F., (1985). An alternative reading for P: Anastasi III, 3-12, JEA, Vol. 71, p: 179

[21] Pernigotti, S., (2005). Scuola e cultura nell' Egitto del Nuevo Regno, Testi del Vicino Orienteantico, Vol. 1, Bd. 6, Claudiana, Brescia.

[22] Leitz, C., (1999). Magical and medical papyri of the new kingdom, Hieratic papyri in the British Museum VII, British Museum press, London.

[23] Quack, J., (2016). Zur frage der botanischen natur des baq-baumes und des von ihm gewonnenen öls mit einem Anhang: pBM 10085 "2-3" rekto. Ein schnippischer dialog zwischen mann und frau?, in: Landgráfová, R. \& Mynářová, J. (eds.) Rich and Great, Studies in Honour of Anthony J. Splinger on the Occasion of his $70^{\text {th }}$ Feast of Thoth, Charles Univ., Prague, pp. 275-290.

[24] Petrie, W., (1908). Athribis, School of Archaeology in Egypt, London.

[25] Gardiner, A., (1955). The Ramesseum papyri, plates, Oxford Univ. press, Oxford.

[26] Lesko, L., (2002). A dictionary of late Egyptian, $2 \mathrm{Vol}_{s}$., $2^{\text {nd }}$ ed., B. C. Scribe Pub., Berkeley.

[27] Wiedemann, A., (1879). Hieratische texte aus den museen zu Berlin und Paris in facsimile mit uebersetzung und sachlichem commentar, Joh. Ambr. Barth, Leipzig.

[28] Erman, A. \& Krebs, F., (1899). Aus den papyrus der Königlichen Museen, W. Spemann, Berlin.
[29] de Garis Davies, N. \& Gardiner, A., (1926). The tomb of Huy, viceroy of Nubia in the Reign of Tutankhamun (No. 40), The Egyptian Exploration Society, London.

[30] Gardiner, A., (1911). Egyptian Hieratic texts, transcribed, translated and annotated. Series I. Literary texts of the new kingdom. Part I: The papyrus Anastasi I and the papyrus Koller together with parallel texts, J. C. Hinrichsche Buchhandlung, Leipzig.

[31] Leitz, C. \& Bommas, V, (2002). Die mythisierung der zeit, die beiden bücherüber die altägyptischen schalttage des magischen pLeiden I 346, Göttinger Orientforschungen IV 37, Wiesbaden 1999, Lingua Aegyptia, Vol. 10, pp. 413-24.

[32] Lepsius, R., (1842). Das todtenbuch der Ägypter, Georg Wigand, Leipzig.

[33] Berlandini-Grenier, J., (1976). Senenmout, stoliste royal, surune statuecube avec Néferourê, BIFAO, Vol. 76, pp. 111-132.

[34] Faulkner, R., (1978). The ancient Egyptian coffin texts, Vol. 3, spells 788-1185, translations and notes, Aris \& Philips, Warminster.

[35] Grapow, H., (1915-17). Religiöse urkunden, $3 \mathrm{Vol}_{\text {s., }}$ JC Hinrichsche Buchhandlung, Leipzig.

[36] Munro, I., (1994). Die totenbuch-handschriften der 18. dynastie im Ägyptischen Museum Cairo, $2 \mathrm{Vol}_{\text {s., }}$ ÄA 54, Otto Harrassowitz, Wiesbaden.

[37] El-Sayed, R., (1975). Documents relating to Sais and his divinities, BdE, Vol. 69, Imprimerie de l'Institut francais d'Archéologie Orientale, Cairo.

[38] Guglielmi, W. \& Buroh, K., (1997). Die eingangssprüche des täglichen tempelrituals nach papyrus Berlin 3055 (I,1-VI,3), in: Dijk, V. \& Brill, J. (eds.) Essays on Ancient Egypt in Honour of Herman te Velde (Egyptological Memoirs 1), Leiden, pp. 101-166.

[39] Calverley, A., (1933). The temple of king Sethos I at Abydos, Vol. I: The chapels of Osiris, Isis and Horus, The Egyptian exploration society, Chicago. 
[40] Wilson, P., (1997). A Ptolemaic Lexikon: A lexicographical study of the texts in the temple of Edfou, OLA 78 , Peeters, Leuven.

[41] Blackman, A., (1998). Gods, priests, and men: Studies in the religion of Pharaonic Egypt, Kegan Paul Int., NY.

[42] Ratie, S., (1968). Le papyrus de Neferouebenef (Louvre III 93), BdE 43, Imprimerie de l'Institut francais d'Archéologie Orientale, Cairo.

[43] Derchain, Ph., (1965). Le papyrus Salt 825 (BM 10051), rituel pour la conservation de la vie en Égypte, in Memories de la classe des lettres 58, Palace of Academies, Brussels.

[44] Faulkner, R., (1977). The ancient Egyptian coffin texts, spells 355787, Vol. 2, translations and notes, Aris \& Philips, Warminster.

[45] Petrie, W., (1902). Abydos, Vol. I, The Egyptian Exploration, London.

[46] Petrie, W., (1903). Abydos, Vol. II, The Egyptian Exploration, London.

[47] Gardiner, A. \& Peet, T., (1952). Inscriptions of Sinai, Part. 1: Introduction and plates, The Egyptian Exploration Society, London.

[48] Gardiner, A. \& Peet, T., (1955). Inscriptions of Sinai, part. 2 Translations and commentary, The Egyptian Exploration Society, London.

[49] Caminos, R., (1972). Another Hieratic manuscript from the library of Pwerem Son of Kiki (Pap. B.M. 10288): To dr. Rosiland L. B. Moss, JEA, Vol. 58, pp. 205-224.
[50] Kees, H. (1943). Farbensymbolik in ägyptischen religiösen texten, Nachrichten der Akademie der Wissenschaften in Göttingen, Philologischhistorische Klasse, Vandenhoeck \& Ruprecht, Göttingen.

[51] Derchain, Ph. (1965). A propos de l'inscription de Mery-Aa (Urk. I, 267, 11), Miszellen, Z $\ddot{A} S$, Vol. 92, pp. 73-74.

[52] Faulkner, R., (1936). The BremnerRhind Papyrus I. A. The songs of Isis and Nephthys, JEA, Vol. 22, pp. 121-140.

[53] Faulkner, R., (1933). The papyrus Bremner-Rhind, (British Museum EA 10188), Fondation Égyptologique Reine Élisabeth, Bruxelles.

[54] De Rachewiltz, B., (1958). Il libro dei morti degli antichi Egiziani, All'Insegna del Pesce d'Oro, Milan.

[55] Gardiner, A., (1935). Hieratic papyri in the British museum, Third series Chester Beatty gift, $2 \mathrm{Vol}_{\text {s., }}$ British Museum, London.

[56] Germond, P., (1981). Sekhmet et la protection du monde, Aeh 9, Éditions de Belles-Lettres, Basel.

[57] Francesco, T., (1999). Sesh, lingue e scritture nell'antico Egitto, inediti dal museo archaeologico di Milano, Electa, Milan.

[58] De Buck, A., (1938). Coffin texts, texts of spells 67-163, Vol. 2, Univ. of Chicago press, Chicago.

[59] Sethe, K., (1922). Die sprache das kennen der stellen der heiligen orte (Totb. Kap. 107-109. 111-116), Z̈̈S, Vol. 57, pp. 1-50. 